\title{
Globus pallidus restricted diffusion associated with vigabatrin therapy
}

Restrição à difusão no globo pálido associado à terapia com vigabatrina

Régis Augusto Reis Trindade1, Betina Wainstein', Líllian Gonçalves Campos', Juliano Adams Pérez1, Marino Muxfeldt Bianchin', Leonardo Modesti Vedolin', Juliana Ávila Duarte'

A magnetic resonance imaging (MRI) exam was performed in an 11-month-old female patient with West syndrome who had been treated with vigabatrin for five months $(131.5 \mathrm{mg} / \mathrm{kg} /$ day). The MRI showed asymptomatic changes (Figures 1, 2 and 3). Vigabatrin-associated MRI abnormalities occur in 10-20\% of treated infants ${ }^{1,2}$. Animal studies have associated the use of vigabatrin with histopathologic abnormalities showing microvacuolization of glial cells and intramyelinic edema ${ }^{3,4}$. Neurologists and neuroradiologists should be aware of, and recognize these changes, as they are mostly transient and may be symptomatic or not. Asymptomatic abnormalities revealed on MRI appear to be dose dependent, according to recent studies ${ }^{5}$.
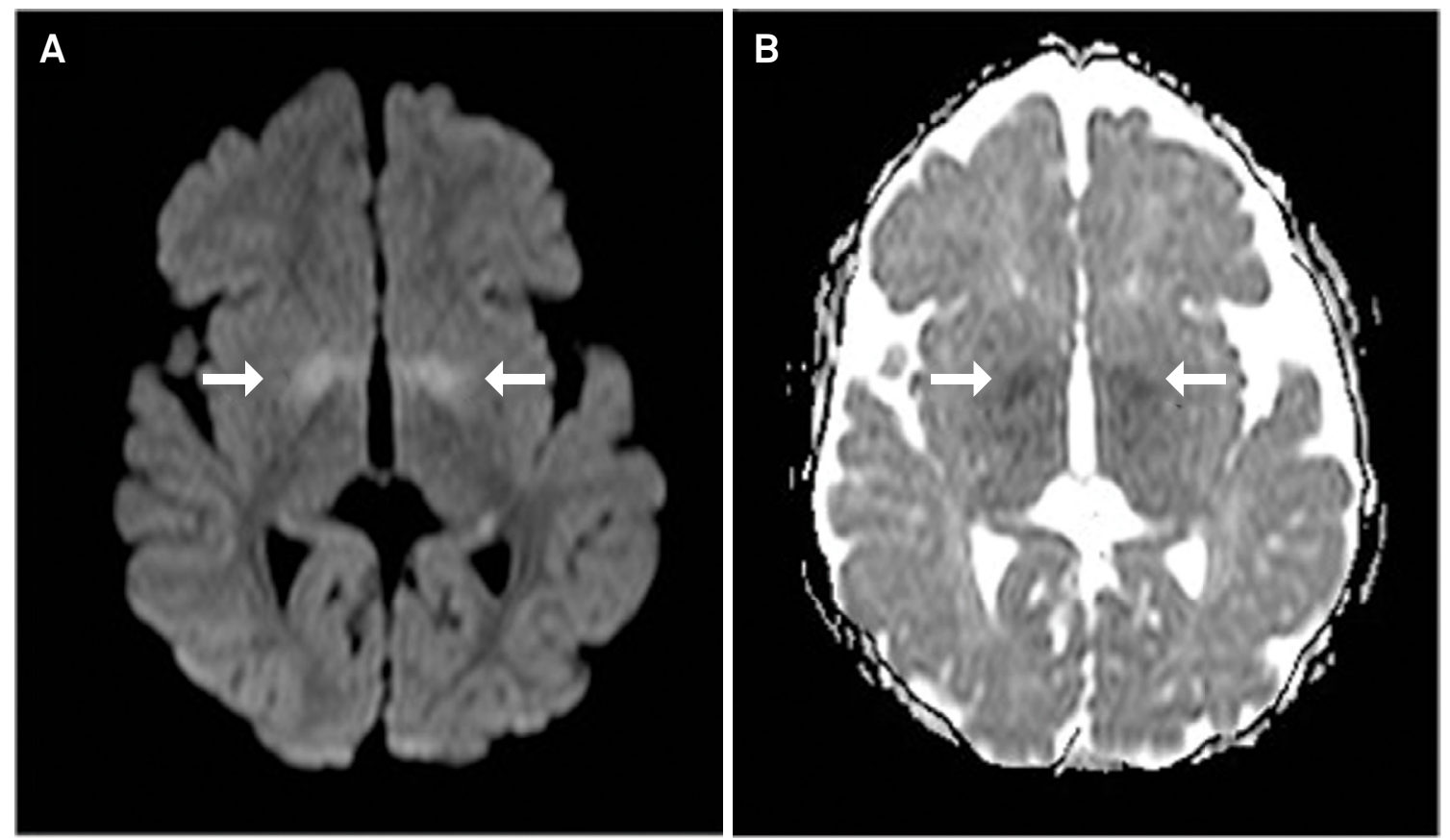

Figure 1. A) Difussion weighted imaging showing restricted diffusion in the globus pallidus bilaterally (arrows). B) Apparent diffusion coefficient map showing hypointensity in the globus pallidus bilaterally, compatible with restricted diffusion (arrows).

'Hospital de Clínicas de Porto Alegre (HCPA), Porto Alegre RS, Brasil. Conflict of interest: There is no conflict of interest to declare.

Correspondence: Juliana Ávila Duarte; R. Ramiro Barcelos, 2350; 90035-903 Porto Alegre RS, Brasil; E-mail: juduarte@hcpa.edu.br Received 05 March 2017; Received in final form 21 November 2017; Accepted 27 November 2017. 


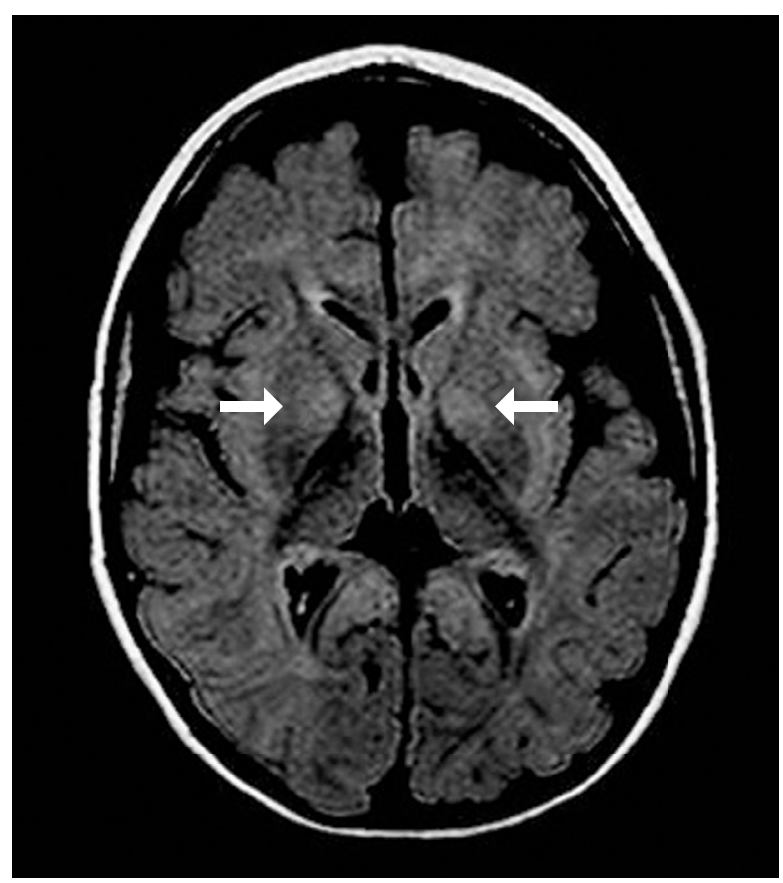

Figure 2. Axial FLAIR-weighted MR image showing high intensity signal in the globus pallidus bilaterally (arrows).

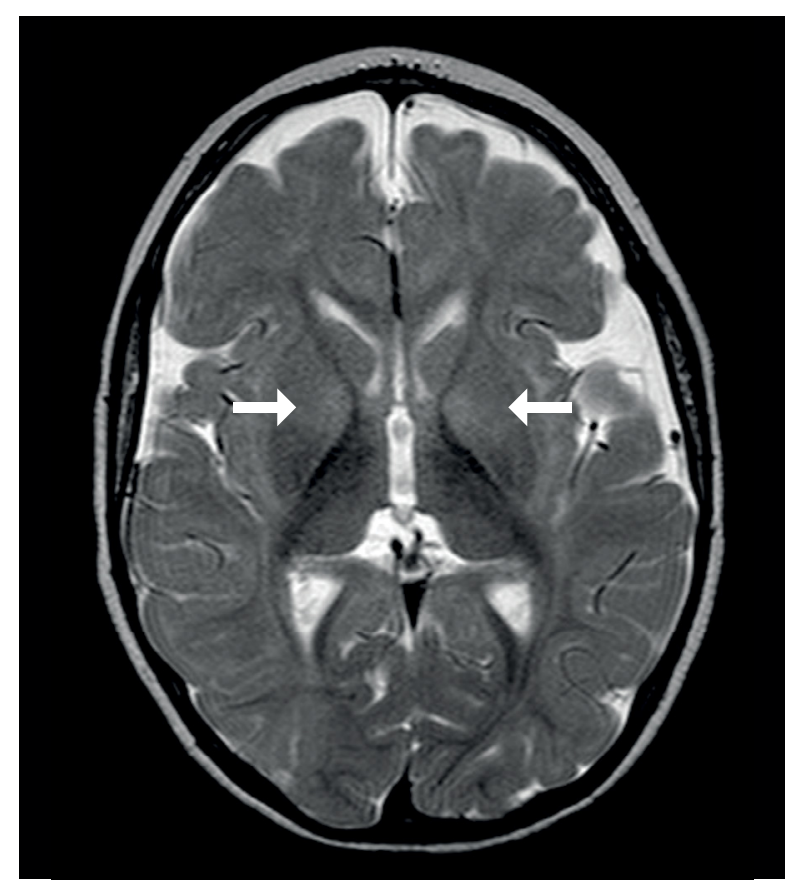

Figure 3. Axial T2-weighted MR image showing symmetric hyperintense foci in the globus pallidus bilaterally (arrows).

\section{References}

1. Wheless JW, Carmant L, Bebin M, Conry JA,

Chiron C, Elterman RD et al. Magnetic resonance imaging abnormalities associated with vigabatrin in patients with epilepsy. Epilepsia. 2009;50(2):195-205. https://doi.org/10.1111/j.1528-1167.2008.01896.x

2. Pearl P, Molloy-Wells E, McClintock WM, Vezina LG, Conry JA, Elling $\mathrm{NJ}$ et al. MRI abnormalities associated with vigabatrin therapy: higher risk in infants? Epilepsia. 2006;47(suppl s4):14.

3. Gibson JP, Yarrington JT, Loudy DE, Gerbig CG, Hurst GH, Newberne JW. Chronic toxicity studies with vigabatrin, a GABA- transaminase inhibitor. Toxicol Pathol. 1990;18(2):225-38. https://doi.org/10.1177/019262339001800201

4. Yarrington JT, Gibson JP, Dillberger JE, Hurst G, Lippert B, Sussman NM et al. Sequential neuropathology of dogs treated with vigabatrin, a GABA-transaminase inhibitor. Toxicol Pathol. 1993 SepOct;21(5):480-9. https://doi.org/10.1177/019262339302100507

5. Hussain SA, Tsao J, Li M, Schwarz MD, Zhou R, Wu JY et al. Risk of vigabatrin-associated brain abnormalities on MRI in the treatment of infantile spasms is dose-dependent. Epilepsia. 2017;58(4):674-82. https://doi.org/10.1111/epi.13712 